\title{
Effect of collection, transport, processing and storage of blood specimens on the activity of lysosomal enzymes in plasma and leukocytes
}

\section{Burin'ㄹ, C. Dutra-Filho², J. Brum ${ }^{3}$, T. Mauricio ${ }^{4}$, M. Amorim ${ }^{5}$ and R. Giugliani ${ }^{1}$}

\author{
${ }^{1}$ Serviço de Genética M édica, Hospital de Clínicas de Porto Alegre and \\ ${ }^{2}$ Departamento de Bioquímica, Universidade Federal do Rio Grande do Sul, \\ Porto Alegre, RS, Brasil \\ ${ }^{3}$ Hospital Sarah Kubischeck, Brasília, DF, Brasil \\ ${ }^{4}$ Serviço de Genética M édica, U niversidade Federal da Paraíba, \\ João Pessoa, PB, Brasil \\ ${ }^{5}$ Departamento de Genética, Universidade Federal do Pará, Belém, PA, Brasil
}

\section{Correspondence \\ M. Burin \\ Serviço de Genética Médica \\ Hospital de Clínicas de Porto Alegre \\ Ramiro Barcelos, 2350 \\ 90035-003 Porto Alegre, RS \\ Brasil \\ Fax: + 55-51-316-8010 \\ E-mail: mburin@ hcpa.ufrgs.br}

Research supported by CN Pq.

Received June 5, 1998

Accepted May 3, 2000

\section{Abstract}

This study was designed to evaluate the effect of different conditions of collection, transport and storage on the quality of blood samples from normal individuals in terms of the activity of the enzymes $\beta$ glucuronidase, total hexosaminidase, hexosaminidase $\mathrm{A}$, arylsulfatase $A$ and $B$-galactosidase. The enzyme activities were not affected by the different materials used for collection (plastic syringes or vacuum glass tubes). In the evaluation of different heparin concentrations (10\% heparin, $5 \%$ heparin, and heparinized syringe) in the syringes, it was observed that higher doses resulted in an increase of at least 1-fold in the activities of $B$-galactosidase, total hexosaminidase and hexosaminidase A in leukocytes, and B-glucuronidase in plasma. When the effects of time and means of transportation were studied, samples that had been kept at room temperature showed higher deterioration with time (72 and $96 \mathrm{~h}$ ) before processing, and in this case it was impossible to isolate leukocytes from most samples. Comparison of heparin and acid citrate-dextrose (ACD) as anticoagulants revealed that $\beta$-glucuronidase and hexosaminidase activities in plasma reached levels near the lower normal limits when ACD was used. In conclusion, we observed that heparin should be used as the preferable anticoagulant when measuring these lysosomal enzyme activities, and we recommend that, when transport time is more than $24 \mathrm{~h}$, samples should be shipped by air in a styrofoam box containing wet ice.

\section{Introduction}

Lysosomal storage diseases are inherited metabolic disorders caused by the deficiency of an enzyme activity, protein activator or transporting protein, leading to the accumulation of specific substrates in the lysosomes,
Key words

- Lysosomal storage diseases

- Lysosomal enzymes

- Inborn errors of metabolism

- Reference laboratories

- Storage of blood samples

- Sample handling which secondarily causes clinical symptoms (1). In most cases, the enzyme assays in blood samples (plasma or leukocytes) provide a definitive diagnosis (2).

The diagnosis of lysosomal storage diseases is usually made at reference centers because of the low individual frequency of 
these disorders and because of the complexity of the laboratory techniques involved. These centers usually receive samples from other laboratories and/or hospitals located far away. As a consequence, some problems may arise regarding the quality of the samples and the activity of some lysosomal enzymes due to their exposure to different conditions of transport and storage. Some authors suggest, for instance, that isolation of leukocytes and plasma for lysosomal enzyme assays should be completed within 18 and $24 \mathrm{~h}$ after blood collection $(3,4)$. This is especially difficult in large countries like Brazil, where facilities for transport are poor.

When blood samples are not processed soon after collection, changes may occur in the levels of sodium, potassium, lactate, ammonia, glucose and $\mathrm{pH}$, among other parameters. These changes occur due to the residual metabolic activity of blood cells, to partial degradation of these cells, and to the imbalance of the processes which influence the half-life of many blood components (5-7). On this basis, it is advisable to identify the optimal time between blood collection at the original service and its processing at the reference laboratory, before alterations of biochemical results occur, as well as the best conditions for sample collection and transport.

Since the data available in the literature on this issue are scarce, we designed this study to evaluate the influence of different conditions of collection, transport and storage of blood samples on the activity of $\beta$ glucuronidase (EC 3.2.1.31), total hexosaminidase (EC 3.2.1.50) and hexosaminidase A, assayed in plasma, and arylsulfatase A (EC 3.1.6.1), ß-galactosidase (EC 3.2.1. 23), total hexosaminidase and hexosaminidase A, assayed in leukocytes.

\section{Material and Methods}

\section{Protocol and sample preparation}

Blood samples were obtained from 132 healthy individuals (males and females) aged 18 to 60 years. Informed consent was obtained from each individual before collection of blood, and the procedures followed were in accordance with the ethical recommendations of our institution. We designed the following 5-stage protocol: a) stage 1 evaluation of the influence of the material used for collection: $16 \mathrm{ml}$ of heparinized blood was collected from five individuals, 8 $\mathrm{ml}$ into a vacuum glass tube and $8 \mathrm{ml}$ into a plastic syringe, and plasma and leukocytes were isolated $30 \mathrm{~min}$ after collection; b) stage 2 - evaluation of the effect of the heparin concentration used for collection on the time until processing after collection: 24 $\mathrm{ml}$ of blood was collected from 15 individuals, divided into three subgroups (10\% heparin, 5\% heparin, and heparinized syringe); each sample was divided into three aliquots of $8 \mathrm{ml}$, kept at $4^{\circ} \mathrm{C}$ and processed at different storage times after collection ( 6 to $8 \mathrm{~h}, 30$ to $32 \mathrm{~h}$, and 54 to $56 \mathrm{~h}$ ); plasma and leukocyte pellets were isolated after storage; c) stage 3 - evaluation of the impact of transportation and shipping time to the laboratory: samples from 60 subjects were collected in three different cities (Brasília, João Pessoa and Belém), with distances from our laboratory ranging from 2000 to $5000 \mathrm{~km}$; in each city two 8-ml aliquots of heparinized blood were collected from 20 individuals into plastic syringes (4 remittances of 5 samples each). One syringe was shipped in a styrofoam box with ice by air, and the other in a cardboard box (without ice) by regular mail. The samples were divided into groups according to the time elapsed between collection and the initial processing operation at the laboratory; d) stage 4 - evaluation of the impact of time between collection and processing and of different temperatures during storage: $16 \mathrm{ml}$ of blood was collected from 40 subjects and divided into two aliquots of $8 \mathrm{ml}$. One of them was stored at room temperature and the other was kept at $4^{\circ} \mathrm{C}$. The samples were divided into four groups 
of 10 , according to time between collection and isolation of plasma and leukocytes which was $24,48,72$ and $96 \mathrm{~h}$; e) stage 5 - comparison of the effect of two anticoagulants at different times between collection and processing: $32 \mathrm{ml}$ of blood was collected from 10 subjects and divided into two aliquots of $16 \mathrm{ml}$. Heparin was used for one of them (heparinized syringe) and $2.8 \mathrm{ml}$ of an acid citrate-dextrose (ACD) solution was added to the other at the following concentrations: $85 \mathrm{mM} \mathrm{Na}$ citrate, $42 \mathrm{mM}$ citric acid, and $136 \mathrm{mM}$ dextrose.

The samples were kept at $4{ }^{\circ} \mathrm{C}$ and divided into two groups ( $8 \mathrm{ml}$ each), according to time between collection and isolation of plasma and leukocytes which was 24 and $72 \mathrm{~h}$.

Leukocytes were isolated by the method of Skoog and Beck (8) using ACD-dextrandextrose for sedimentation. Plasma and leukocytes were kept frozen at $-40^{\circ} \mathrm{C}$ until the time for enzyme assays. Lysosomal enzymes were released by 3 cycles of freezing and thawing. Protein was measured by the method of Lowry et al. (9).

\section{Enzyme assays}

All reagents and substrates were purchased from Sigma. $\beta$-Galactosidase was assayed by the method of Suzuki (10). Leukocytes were incubated for $1 \mathrm{~h}$ at $37^{\circ} \mathrm{C}$ using $1.33 \mathrm{mM}$ 4-methylumbelliferyl- $\beta$-D-galactoside diluted in $0.1 \mathrm{M}$ citrate-phosphate buffer, $\mathrm{pH} 4.0$, containing $0.2 \mathrm{M} \mathrm{NaCl}$. The reaction was stopped with $0.5 \mathrm{M}$ glycine$\mathrm{NaOH}$ buffer, $\mathrm{pH} 10.3$, and fluorescence was measured.

Hexosaminidases were assayed by the method of Singer et al. (11). Because hexosaminidase $\mathrm{A}$ is labile at $50^{\circ} \mathrm{C}, 50 \mu \mathrm{l}$ of leukocytes (diluted 1:60) and plasma (diluted $1: 30$ ) were incubated for $3 \mathrm{~h}$ at $50^{\circ} \mathrm{C}$ in $1 \mathrm{M}$ citrate/ $0.2 \mathrm{M}$ phosphate buffer, $\mathrm{pH} 4.45$, containing $0.75 \%$ bovine serum albumin. These samples and duplicates kept at $0^{\circ} \mathrm{C}$ were then incubated at $37^{\circ} \mathrm{C}$ for $1 \mathrm{~h}$ with 1
mM4-methylumbelliferyl-N-acetyl-ß-D-glucopyranoside. The reaction was stopped with $0.5 \mathrm{M}$ glycine- $\mathrm{NaOH}$ buffer, $\mathrm{pH} 10.3$, and fluorescence was measured.

ß-Glucuronidase was assayed by the method of Beaudet et al. (12). Plasma was incubated for $1 \mathrm{~h}$ at $37^{\circ} \mathrm{C}$ with $2 \mathrm{mM} \mathrm{4-}$ methylumbelliferyl- $\beta$-D-glucuronide in $0.5 \mathrm{M}$ sodium acetate buffer, $\mathrm{pH}$ 3.0. The reaction was stopped with $0.5 \mathrm{M}$ glycine- $\mathrm{NaOH}$ buffer, $\mathrm{pH} 10.3$, and fluorescence was measured.

Arylsulfatase A was assayed by the method of Lee-Vaupel and Conzelmann (13). Leukocytes were incubated at $0^{\circ} \mathrm{C}$ with 10 $\mathrm{mM}$ p-nitrocatechol sulfate in $0.5 \mathrm{M}$ sodium acetate buffer, $\mathrm{pH} 5.0$, containing $0.5 \mathrm{mM}$ sodium pyrophosphate and $10 \% \mathrm{NaOH}$. The reaction was stopped with $1 \mathrm{M} \mathrm{NaOH}$ and absorbance was measured at $515 \mathrm{~nm}$.

The enzyme activities are reported as nmol substrate hydrolyzed $\mathrm{h}^{-1} \mathrm{mg}$ protein ${ }^{-1}$ (leukocytes) and nmol substrate hydrolyzed $\mathrm{h}^{-1} \mathrm{ml}$ plasma ${ }^{-1}$. Hexosaminidase $\mathrm{A}$ is reported as percentage of total hexosaminidase activity. All assays were performed in duplicate.

The normal reference ranges for each enzyme are 5-20 $\mathrm{nmol} \mathrm{h}^{-1} \mathrm{mg}$ protein ${ }^{-1}$ for arylsulfatase A, 70-280 $\mathrm{nmol} \mathrm{h}^{-1} \mathrm{mg}_{\text {protein }}{ }^{-1}$ for B-galactosidase, $552-1662 \mathrm{nmol} \mathrm{h}^{-1} \mathrm{mg}$ protein $^{-1}$ for total hexosaminidase, $48-89 \%$ for hexosaminidase A in leukocytes, 30-300 $\mathrm{nmol} \mathrm{h}^{-1} \mathrm{ml}^{-1}$ for $ß$-glucuronidase, 1000-2860 $\mathrm{nmol} \mathrm{h} \mathrm{h} \mathrm{ml}^{-1}$ for total hexosaminidase, and $45-72 \%$ for hexosaminidase $\mathrm{A}$ in plasma.

\section{Statistical analysis}

The data obtained for the enzyme activity measurements in stage 1 were analyzed by the paired Student $t$-test, and those obtained in the other stages by two-way ANOVA and Duncan's test, when necessary. Data for stages 3 and 4 were analyzed by the chisquare test to determine the proportion of samples suitable for analysis. A difference was considered significant when $\mathrm{P}<0.05$. 
Figure 1 - Comparison of leukocyte (A) and plasma (B) activities of different lysosomal enzymes when blood collection was performed with a plastic syringe (syr) or with a vacuum glass tube (vac). Values are the mean \pm SEM and are reported as nmol $\mathrm{h}^{-1} \mathrm{mg}$ protein ${ }^{-1}$ and $\mathrm{nmol} \mathrm{h}^{-1}$ $\mathrm{ml}^{-1}$ for leukocytes and plasma, respectively. asa, Arylsulfatase A; B-gal, ß-galactosidase; hex (x 0.1 ), hexosaminidase; \%hex $A$, hexosaminidase A percentage; B-glu, ß-glucuronidase.

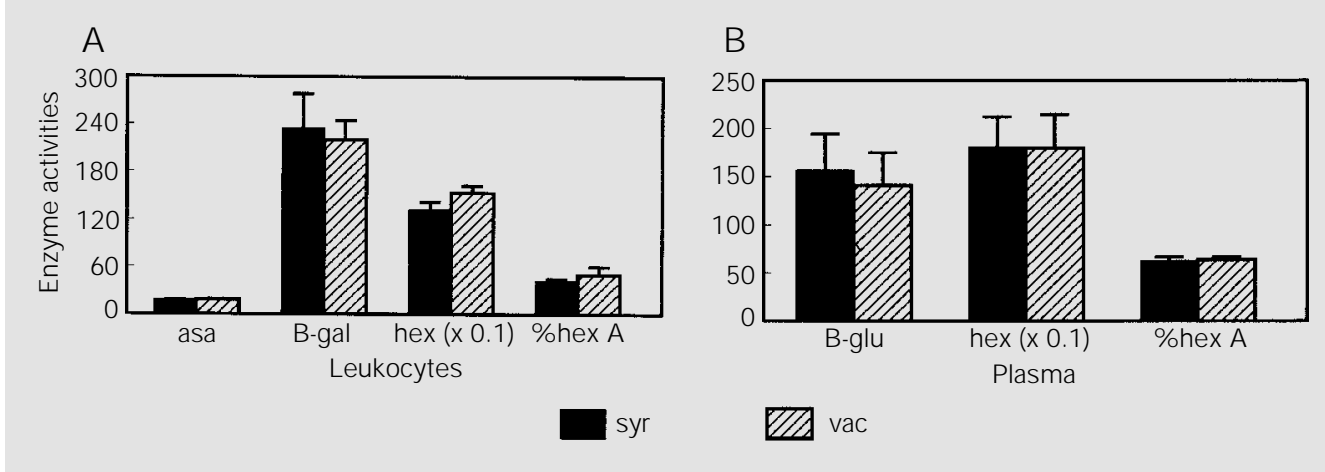

Table 1 - Distribution of plasma and leukocytes from 60 individuals divided into two aliquots according to mode of transportation and time of processing.

$* \mathrm{P}<0.05$ compared to $24 \mathrm{~h}$ (chi-square test).

Number of samples isolated $x$ samples not isolated (in parentheses)

\begin{tabular}{llll} 
& $24 \mathrm{~h}$ & $48 \mathrm{~h}$ & $72 / 96 \mathrm{~h}$ \\
\hline $\begin{array}{l}\text { Plasma } \\
\quad \begin{array}{c}\text { Air company } \\
\text { (refrigerated) }\end{array}\end{array}$ & $45(1)$ & $10(0)$ & $5(0)$ \\
$\begin{array}{c}\text { Regular mail } \\
\text { (room temperature) }\end{array}$ & $35(0)$ & $10(0)$ & $15(1)$ \\
$\begin{array}{c}\text { Leukocytes } \\
\text { Air company } \\
\text { (refrigerated) }\end{array}$ & $45(1)$ & $10(0)$ & $5(0)$ \\
$\quad \begin{array}{l}\text { Regular mail } \\
\text { (room temperature) }\end{array}$ & $35(0)$ & $10(0)$ & $15(10)^{*}$
\end{tabular}

\section{Results}

Figure 1 shows the influence of the material used for collection on the enzyme activities studied. It can be seen that no significant difference was observed between blood samples collected into a vacuum glass tube and into a plastic syringe for any of the parameters evaluated.

Next, we evaluated the influence of heparin concentration (10\% heparin, 5\% heparin, and heparinized syringe) at different times ( 6 to $8 \mathrm{~h}, 30$ to $32 \mathrm{~h}$, and 54 to $56 \mathrm{~h}$ ) between collection and processing (Figure 2). The activities of arylsulfatase A in leuko- cytes and hexosaminidase $\mathrm{A}$ in plasma were not affected by different heparin concentrations at any time of storage. The effect of heparin concentration was observed mainly when blood was collected with $10 \%$ heparin, compared to a heparinized syringe. The $B-$ galactosidase, total hexosaminidase, hexosaminidase A (leukocytes), and B-glucuronidase (plasma) enzymes exhibited higher activities with this concentration. In addition, various enzyme activities ( $ß$-galactosidase, hexosaminidase $\mathrm{A}$ in leukocytes, and B-glucuronidase and total hexosaminidase in plasma) exhibited significant differences according to the period of processing. In plasma, $\beta$-glucuronidase and total hexosaminidase activities diminished, compared to $6 / 8 \mathrm{~h}$ of storage. In leukocytes the same effect occurred for hexosaminidase A, whereas the opposite effect was seen for Bgalactosidase.

When analyzing the impact of type of transportation to the laboratory and shipping time (the time between collection in the different cities and initial processing at our laboratory), we decided first to divide the 60 samples into 3 groups, i.e., samples processed within 24,48 and 72/96 h after collection. One blood sample was lost during transportation, and one plasma during processing (Table 1). As observed in this table, leukocytes could not be isolated from 10 of 15 samples sent by regular mail (room temperature) arriving after 72 to $96 \mathrm{~h}$. When analyzing the number of leukocyte samples 
which could be isolated adequately after arriving by air company or regular mail, a significant failure in obtaining leukocytes was observed for samples shipped by regular mail after 72/96 h ( $\mathrm{P}<0.05$, chi-square test).

Figure 3 shows that there was no signifi- cant effect of type of transport or time of processing on the activities of arylsulfatase $A$ in leukocytes, and of B-glucuronidase, total hexosaminidase and hexosaminidase $\mathrm{A}$ in plasma. However, the impact of transport (temperature of storage) was observed on

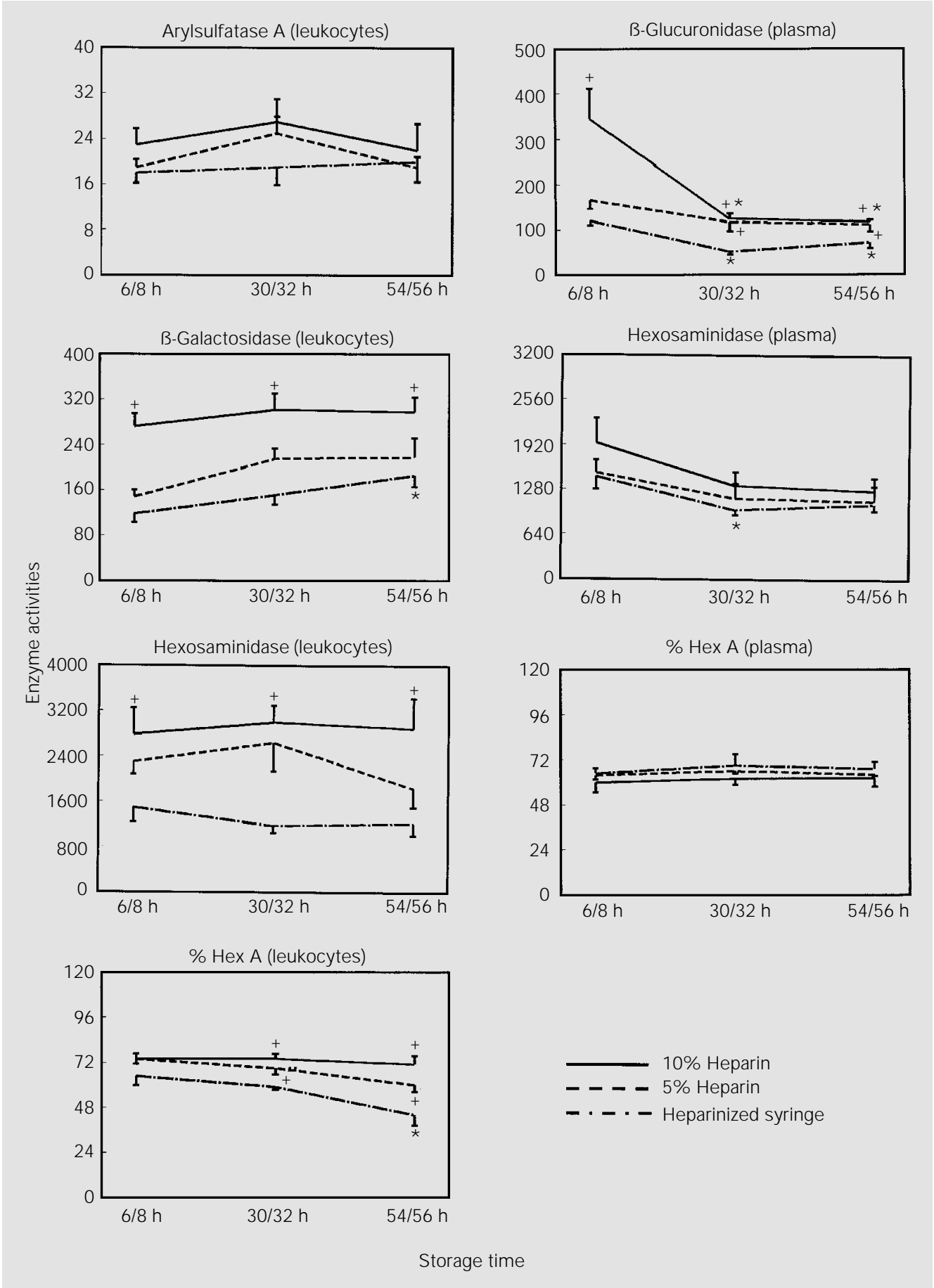

Figure 2 - Effect of different heparin concentrations and storage times on the activity of lysosomal enzymes. Values are the mean \pm SEM and are reported as $\mathrm{nmol} \mathrm{h}^{-1} \mathrm{mg}^{-1}$ protein ${ }^{-1}$ and $\mathrm{nmol} \mathrm{h}^{-1} \mathrm{ml}^{-1}$ for leukocytes and plasma, respectively. Hexosaminidase A (Hex A) is reported as \% hexosaminidase. $* \mathrm{P}<0.05$ compared to $6 / 8 \mathrm{~h}$ at the same heparin concentration. ${ }^{+} \mathrm{P}<0.05$ compared to the heparinized syringe group at the same storage time. 
Figure 3 - Effect of different means of transportation and shipping times on the activity of lysosomal enzymes. Values are the mean \pm SEM and are reported as nmol h-1 mg protein-1 and $\mathrm{nmol} \mathrm{h}^{-1} \mathrm{ml}^{-1}$ for leukocytes and plasma, respectively. Hexosaminidase $A$ (Hex A) is reported as \% hexosaminidase. $* \mathrm{P}<0.05$ compared to $24 \mathrm{~h}$ considering the same means of transportation. ${ }^{+} \mathrm{P}<0.05 \mathrm{com}$ pared to samples shipped by air considering the same shipping time. the activities of $\beta$-galactosidase, total hexosaminidase, and hexosaminidase $\mathrm{A}$ in leukocytes. Lower total hexosaminidase activity and hexosaminidase A percentage were observed at $24 \mathrm{~h}$ for samples shipped by regular mail without refrigeration, when com-

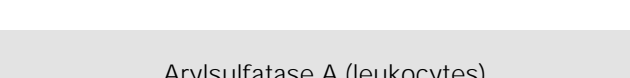

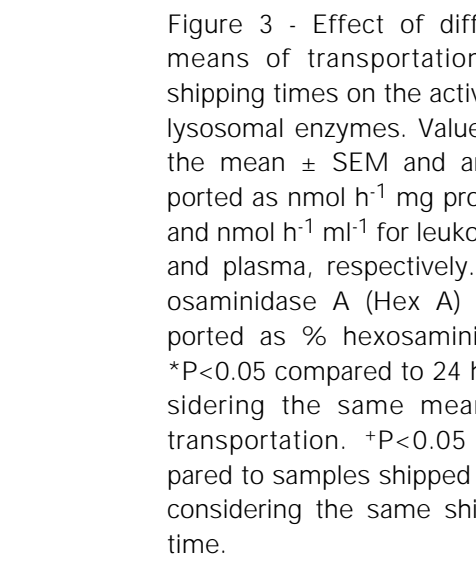

we observed that $ß$-galactosidase exhibited a
higher activity when samples arrived by regu-
analyzed within 
hibited higher activities in samples sent by regular mail. On the other hand, when studying time of processing, total hexosaminidase and hexosaminidase A activities in leukocytes were lower at 48 and 72/96 h, and at $72 / 96 \mathrm{~h}$, respectively, in samples shipped by air with refrigeration when compared to samples tested at $24 \mathrm{~h}$.

In another set of experiments, the impact of time between sample collection and sample processing in the laboratory was evaluated (Figure 4). In this stage it was not possible to
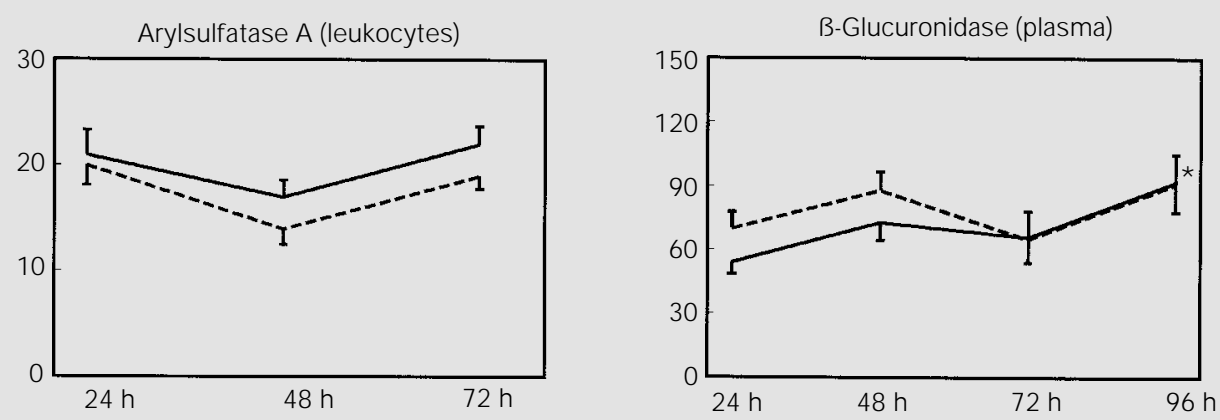

Figure 4 - Effect of different temperatures and times of storage. Values are the mean \pm SEM and are reported as $\mathrm{nmol} \mathrm{h}^{-1} \mathrm{mg}$ protein ${ }^{-1}$ and $\mathrm{nmol} \mathrm{h}^{-1} \mathrm{ml}^{-1}$ for leukocytes and plasma, respectively. Hexosaminidase A (Hex $A$ ) is reported as \% hexosaminidase. $* \mathrm{P}<0.05$ compared to 24 h. $+\mathrm{P}<0.05$ compared to the refrigerated group at the same storage time.
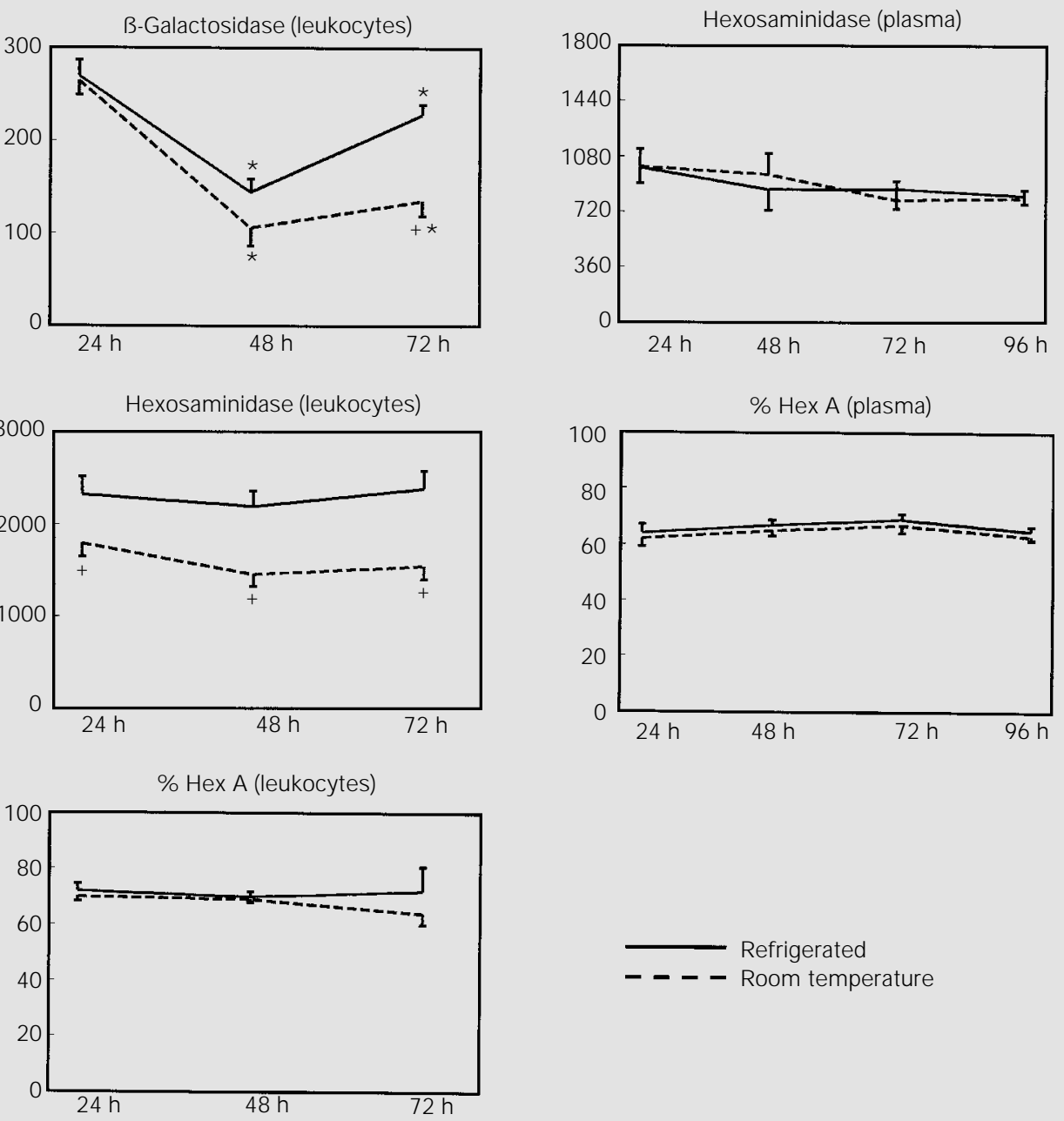

Refrigerated

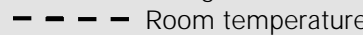

Storage time 
Figure 5 - Effect of different anticoagulants for samples processed at different times after collection. Values are means \pm SEM and are reported as nmol $\mathrm{h}^{-1} \mathrm{mg}$ protein-1 and nmol $\mathrm{h}^{-1}$ $\mathrm{ml}^{-1}$ for leukocytes and plasma, respectively. Hexosaminidase $A$ $(\operatorname{Hex} A)$ is reported as \% hexosaminidase. $* \mathrm{P}<0.05 \mathrm{com}$ pared to the heparinized group at the same storage time. ACD, Acid citrate-dextrose. separate leukocytes from any of the 10 samples kept at room temperature for $96 \mathrm{~h}$ before processing (Table 2). When we analyzed these data by the chi-square test we found a significant difference $(\mathrm{P}<0.01)$ between room temperature and $4^{\circ} \mathrm{C}$ after $72 \mathrm{~h}$

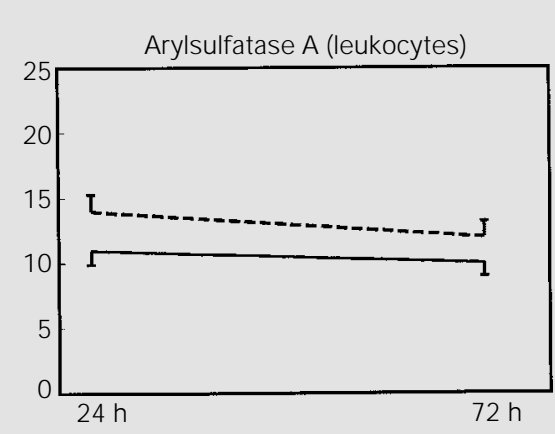

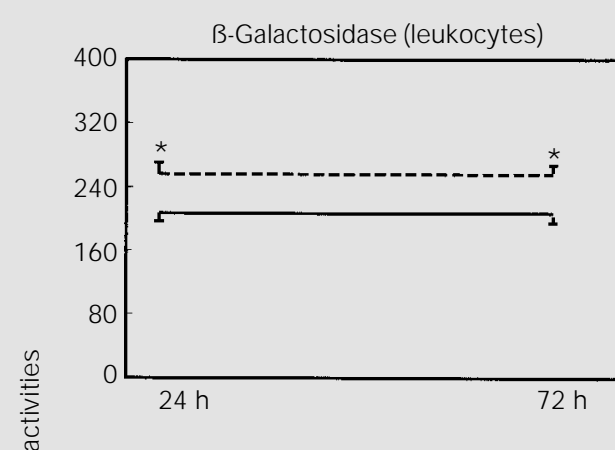
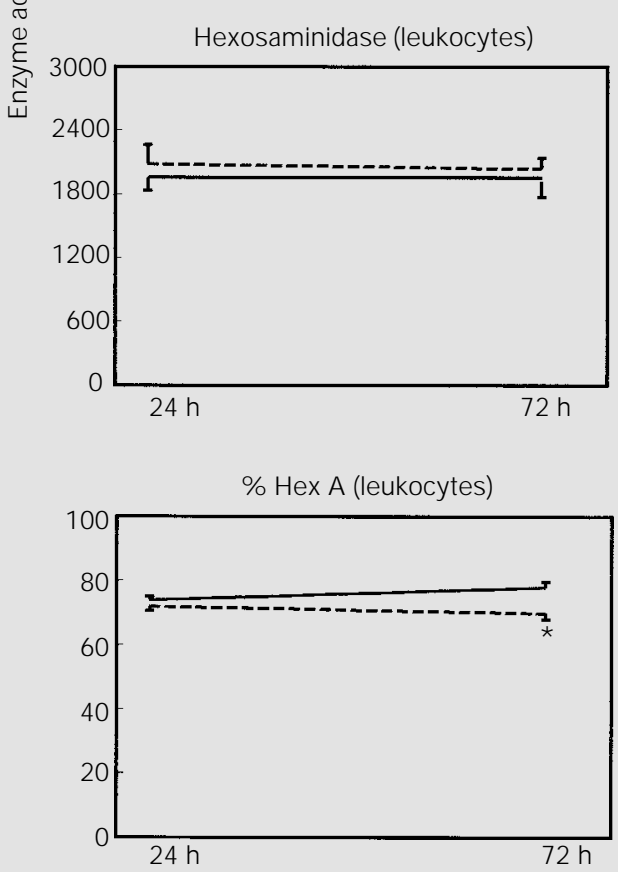

and $96 \mathrm{~h}$. These results confirm those observed when samples were sent by regular mail at 72/96 h (Table 1). It can be seen in Figure 4 that total hexosaminidase activities in leukocytes were lower at all storage times studied for samples kept at room tempera-
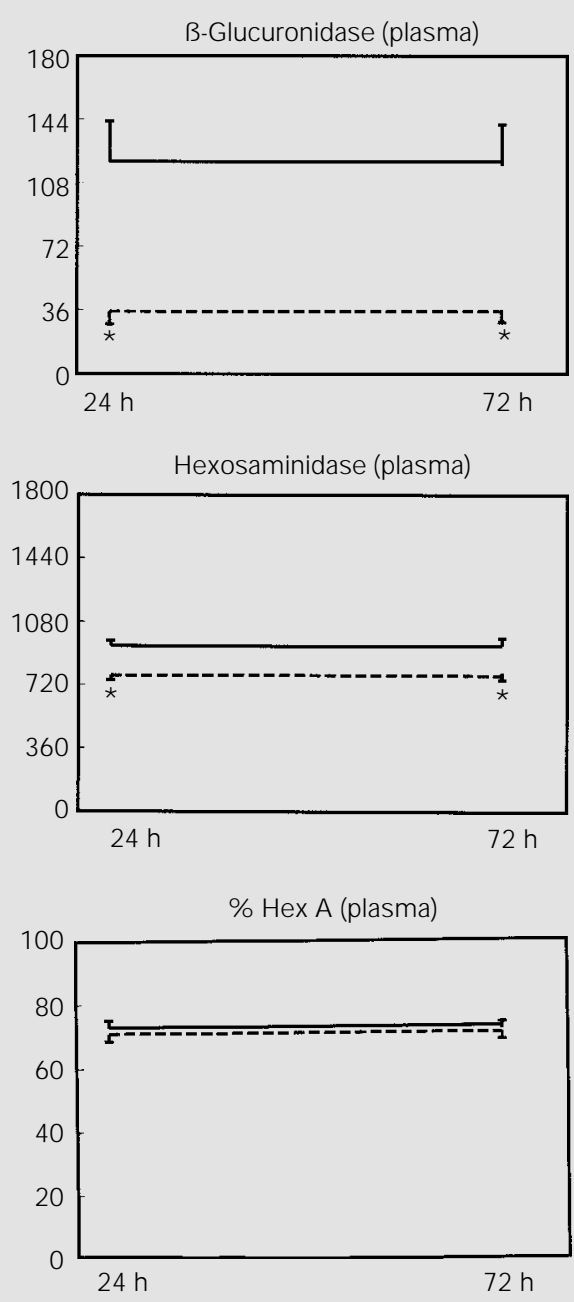

Storage time 
ture compared to samples kept at $4^{\circ} \mathrm{C}$. The same occurred for $\beta$-galactosidase activity after $72 \mathrm{~h}$ of storage. For this enzyme, leukocyte activities decreased when compared to samples stored for $24 \mathrm{~h}$. Moreover B-glucuronidase showed higher activity in samples stored for $96 \mathrm{~h}$ at $4^{\circ} \mathrm{C}$.

Finally, the comparison between ACD and heparin as anticoagulants at different times (24 and $72 \mathrm{~h}$ ) of sample processing is shown in Figure 5. First, it can be observed that there was no effect of different times of processing on the enzyme activities for either anticoagulant. However, when analysis was performed for ACD compared to heparin, higher activities of $\beta$-galactosidase in leukocytes were observed for ACD at both processing times. In contrast, plasma $\beta$-glucuronidase and total hexosaminidase activities were lower when ACD was used at both processing times, while the same occurred at $72 \mathrm{~h}$ of sample processing for hexosaminidase A activity in leukocytes.

\section{Discussion}

In the present study, no difference was observed between blood collected with a vacuum glass tube and blood collected with a plastic syringe. This finding is in contrast to the data reported by Sasakawa and Tokunaga (6), who demonstrated that blood stored in plastic bags showed smaller variations due to the air permeability of the material, which preserved better the $\mathrm{pH}$ and blood viscosity when compared to blood stored in glass bottles.

The choice of anticoagulant for biochemical analysis is very important and depends directly on the assay to be performed. EDTA, for instance, has a chelating effect which causes loss of activity of some lysosomal enzymes (14). Some authors refer to heparin as a powerful inhibitor of leukocytic lysosomal enzymes (15-18) when added directly to the incubation medium. Although a very low concentration of heparin may be present dur-
Table 2 - Distribution of leukocyte samples according to time between collection and processing and storage temperature.

$* \mathrm{P}<0.05$ compared to $24 \mathrm{~h}$ (chi-square test). $\mathrm{RT}$, Room temperature.

\begin{tabular}{lrrrr}
\hline $\begin{array}{l}\text { Storage } \\
\text { condition }\end{array}$ & \multicolumn{4}{c}{$\begin{array}{c}\text { Number of samples isolated } \mathrm{x} \\
\text { samples not isolated (in parentheses) }\end{array}$} \\
\cline { 2 - 5 } & $24 \mathrm{~h}$ & $48 \mathrm{~h}$ & $72 \mathrm{~h}$ & $96 \mathrm{~h}$ \\
\hline RT & $10(0)$ & $8(2)$ & $4(6)^{*}$ & $0(10)^{*}$ \\
$4^{\circ} \mathrm{C}$ & $10(0)$ & $10(0)$ & $10(0)$ & $10(0)$
\end{tabular}

ing assays measuring plasma enzyme activities, only traces of heparin (if any) are expected after the leukocyte preparation procedure. However, there are many biochemical genetic laboratories which use heparin as anticoagulant $(3,4,19-21)$, and some reference centers recommend the collection of blood with heparin concentrations as high as 10\% (Shin Y, personal communication). In the present study, higher lysosomal enzyme activities were observed when blood was collected with $10 \%$ heparin. In addition, the activities seemed to be better preserved during different periods of processing when blood was collected with the higher heparin concentration. ß-Glucuronidase activity was affected by heparin and time of processing, with the highest activity being observed within $6 / 8 \mathrm{~h}$ with $10 \%$ heparin, in agreement with Triebling et al. (22), who reported that heparin raised the total activity of B-glucuronidase.

Furthermore, there was a clear effect of time of transportation. In many cases samples are processed more than $48 \mathrm{~h}$ after collection due to the large number of steps involved between collection and processing at the reference laboratory, where large distances are an important factor. Firstly, we observed a clear deterioration of samples sent by regular mail. The failure to obtain leukocytes occurred in samples processed 72 and $96 \mathrm{~h}$ after collection and shipped at room temperature. Leukocyte pellets could not be iso- 
lated from 10 of 15 blood specimens arriving after 72-96 h. This observation agrees with the findings of Branum et al. (23), who studied the effect of heparin and ACD on leukocyte yield and function, and on lysosomal enzyme activity. According to these authors, ACD is the best choice of anticoagulant for those specimens submitted to leukocyte isolation after a time longer than $48 \mathrm{~h}$. ACD is a good anticoagulant for blood preservation $(24,25)$, while heparin has been cited only as an anticoagulant and not as a preservative (26). Samples which came by regular mail exhibited higher enzyme activities in most cases. However, a higher number of unsuccessful leukocyte preparations was observed under these conditions. Bailey and Bove (5) demonstrated that routine transportation, processing and handling of blood may lead to alterations in the biochemical characteristics of the sample.

The results obtained when the effect of transport was eliminated emphasize the difficulties for the isolation of leukocytes from samples kept at room temperature for long periods of time. When the samples were collected at our laboratory (stage 4), we also observed smaller variations in the activity of the enzymes studied in comparison to the samples which traveled long distances, indicating that transport itself influences the behavior of the enzymes.

Arylsulfatase A activity was highly stable under all conditions analyzed here, in agreement with Draper et al. (27). The activities of B-galactosidase, total hexosaminidase and hexosaminidase A in leukocytes varied independently of the processing conditions. Lombardo et al. (28) consider B-galactosidase to be the most labile enzyme. They observed that $\beta$-galactosidase and $\beta$-glucuronidase are released to a great extent from leukocytes and platelets, leading to an in- crease in plasma activities during refrigerated storage of blood (7). This seems to be the case for the increase in $\beta$-glucuronidase activity observed in the present study.

Since the literature (23) indicates the existence of other anticoagulants such as ACD which preserves leukocytes better than heparin, we compared the effects of ACD and heparin. The results indicate that the activities of $\beta$-glucuronidase and total hexosaminidase in plasma reached levels near the lower normal limits when ACD was used. This kind of information is important if one desires to maintain consistent normal-range values for all samples tested, particularly for the detection of carriers and affected individuals. On the other hand, our findings are in agreement with Branum et al. (23) in terms of arylsulfatase A activity in leukocytes, which did not differ with the use of one anticoagulant or the other. According to these results, the use of a heparinized syringe seems to be preferable to ACD. Heparin, which is an inexpensive anticoagulant used worldwide, has been used in our routine for a long time, and all normal ranges of lysosomal enzyme activities have been well established in the laboratory with this anticoagulant.

On the basis of the data obtained, we propose that 1) blood can be collected either into a glass tube or into a heparinized plastic syringe, the latter being preferable for transport since it is an unbreakable material; 2) the material can be transported in cardboard boxes by regular mail (without refrigeration) only when the transportation time does not exceed $24 \mathrm{~h}$; otherwise, it is advantageous to ship the sample in a styrofoam box with wet ice by air or by courier service, and 3 ) it is preferable to use heparin instead of ACD as anticoagulant to analyze lysosomal enzyme activities in plasma or leukocytes. 


\section{References}

1. Tager J M, J onsson LM, Aerts J G, Oude EJ , Schram AW, Erickson AH \& Barranger JA (1984). Metabolic consequences of genetic defects in lysosomes. Biochemical Society Transactions, 12: 902-905.

2. Lowden J A (1982). Enzymological diagnosis of lysosomal storage diseases. In: Willey AM, Carter TP, Kelly S \& Porter IH (Editors), Clinical Genetics - Problems in Diagnosis and Counseling. Academic Press, New York.

3. Wenger DA \& Williams C (1991). Screening for lysosomal disorders. In: Hommes FA (Editor), Techniques in Diagnostic Human Biochemical Genetics - A Laboratory Manual. Wiley-Liss Inc., New York.

4. Landels EC, Ellis IH, Bobrow $M \&$ Fensom AH (1991). Tay-Sachs disease heterozygote detection: use of centrifugal analyser for automation of hexosaminidase assays with two different artificial substrates. J ournal of Medical Genetics, 28: 101-109.

5. Bailey DN \& Bove J R (1975). Chemical and hematological changes in stored CPD blood. Transfusion, 15: 244-249.

6. Sasakawa S \& Tokunaga E (1976). Physical and chemical changes of ACD preserved blood: a comparison of blood in glass bottles and plastic bags. Vox Sanguinis, 31: 199-210.

7. Lombardo A, Goi G, Guagnellini E, Fabi A, Sciorelli G, Burlina $A B \&$ Tettamanti $G$ (1984). Behaviour of several enzymes of lysosomal origin in human plasma during whole blood storage. Clinica Chimica Acta, 143: 343-353.

8. Skoog WA \& Beck WS (1956). Studies on the fibrogen, dextran and phytohemagglutinin methods of isolating leukocytes. Blood, 11: 436-454.

9. Lowry $\mathrm{OH}$, Rosebrough NJ, Farr $\mathrm{AL} \&$ Randall RJ (1951). Protein measurement with the Folin phenol reagent. J ournal of Biological Chemistry, 193: 265-275.

10. Suzuki K (1977). Globoid cell leukodystrophy (Krabbe disease) and GM 1-gangliosidosis. In: Glew RH \& Peters SP (Editors),
Practical Enzymology of Sphingolipidoses. A.R. Liss, New York.

11. Singer J D, Cotlier E \& Krimmer R (1973). Hexosaminidase $A$ in tears and saliva for rapid identification of Tay-Sachs diseases and its carriers. Lancet, 2: 116-119.

12. Beaudet AL, Diferrante NM, Ferry GD, Nichols BL \& Mullins CE (1975). Variation in the phenotypic expression of B-glucuronidase deficiency. Pediatrics, 86: 388394.

13. Lee-Vaupel M \& Conzelmann E (1987). A simple chromogenic assay for arylsulfatase A. Clinica Chimica Acta, 164: 171180.

14. Kolodny EH \& Mumford RA (1976). Human leukocyte acid hydrolases: characterization of eleven lysosomal enzymes and study of reaction conditions for their automated analysis. Clinica Chimica Acta, 70: 247-257.

15. Avila J L \& Convit J (1975). Inhibition of leucocytic lysosomal enzymes by glycosaminoglycans in vitro. Biochemical J ournal, 152: 57-64.

16. Avila J L \& Convit J (1976). Physicochemical characteristics of the glycosaminoglycan lysosomal enzyme interaction in vitro. Biochemical J ournal, 160: 129-136.

17. Mikulíková $D \&$ Trnavský K (1982). Influence of a glycosaminoglycan polysulfate (arteparon) on lysosomal enzyme release from human polymorphonuclear leukocytes. Zeitschrift für Rheumatologie, 41: 50-53.

18. Lund-Hansen T, Hoyer PE \& Andersen $\mathrm{H}$ (1984). A quantitative cytochemical assay of ß-galactosidase in single cultured human skin fibroblasts. Histochemistry, 81: 321-330.

19. Singer HS, Nankervis GA \& Schafer IA (1972). Leukocyte beta-galactosidase activity in the diagnosis of generalized GM 1 gangliosidosis. Pediatrics, 49: 352-361.

20. Raghavan S, Gajewski A \& Kolodny EH (1977). GM 1-Ganglioside ß-galactosidase in leukocytes and cultured fibroblasts.
Clinica Chimica Acta, 81: 47-56.

21. Mutoh T, Kiuchi K, Sobue I \& Naoi M (1984). Application of a GM 1 ganglioside ß-galactosidase microassay method to diagnosis of GM 1 gangliosidosis. Clinica Chimica Acta, 140: 223-230.

22. Triebling A, Dlugosz J, Brzozowski J, Lukaszewicz W \& Gabryelewicz A (1979). Heparin effect on the activity of certain lysosomal hydrolases in dog pancreas (in vivo investigations). Acta Physiologica Polonica, 30: 527-532.

23. Branum $E$, Cummins $L$, Bartilson $M$, Hopper M, Pruett S \& O'Brien J F (1988). Effect of two anticoagulants on leukocyte yield and function, and on lysosomal enzyme activity. Clinical Chemistry, 34: 110113.

24. Schechter DC \& Swan H (1962). Biochemical alterations of preserved blood. Archives of Surgery, 84: 269-276.

25. Moore SB, Beckala H, DeGoey $S \&$ Leavelle $D$ (1981). A report on the use of ACD (solution B) as whole blood transport medium for recovery of lymphocytes for HLA typing. In: Zachary AA \& Braun WE (Editors), Laboratory Manual, American Association for Clinical Histocompatibility Testing. American Association for Clinical Histocompatibility Testing, New York.

26. Walker RH (1990). Blood and blood components: preparation, storage, and shipment. In: Walker RH (Editor), Technical Manual. American Association of Blood Banks, Arlington.

27. Draper RK, Fiskum GM \& Edmond J (1976). Purification, molecular weight, amino acid and subunit composition of arylsulfatase $A$ from human liver. Archives of Biochemistry and Biophysics, 177: 525538.

28. Lombardo A, Caimi L, Marchesini S, Goi GC \& Tettamanti G (1980). Enzymes of lysosomal origin in human plasma and serum: assay conditions and parameters influencing the assay. Clinica Chimica Acta, 108: $337-346$. 